\title{
PENINGKATAN HASIL BELAJAR MATERI MENGIDENTIFIKASI KELANGSUNGAN HIDUP MAKHLUK HIDUP MELALUI ADAPTASI, SELEKSI ALAM DAN PERKEMBANGBIAKAN MENGGUNAKAN MODEL PEMBELAJARAN MIND MAP
}

\author{
Anik Widiarti ${ }^{1)}$ \\ 1) SMP Negeri 2 Trenggalek \\ widiarti.anik@gmail.com
}

\begin{abstract}
ABSTRAK: Prosentase ketuntasan klasikal dari kelas yang dipegang peneliti masih dibawah $80 \%$. Capaian nilai rata-rata kelas juga kurang memuaskan hanya berkisar 65,00. Penelitian ini dilakukan dengan menggunakan tahap-tahap pelaksanaan yang didalamnya terdapat empat tahap kegiatan yaitu: perencanaan, pelaksanaan tindakan, observasi dan refleksi. Penelitian tindakan kelas ini dilaksanakan di kelas IX D karena ketuntasan kelas ini adalah yang paling rendah dibandingkan dengan kelas-kelas yang lain. Hasil dari tindakan pada penelitian ini terlihat adanya perkembangan setelah menerapkan model pembelajaran Mind Map. Pada siklus 1 prosentase ketuntasan klasikal pada siklus 1 sebesar $76,00 \%$ dan meningkat menjadi $88,00 \%$ pada siklus 2. Demikian juga dengan pencapaian nilai rata-rata yang meningkat dari 69,20 pada saat siklus 1 menjadi 78,20 pada siklus 2. Oleh karena itu dapat disimpulkan bahwa penelitian tindakan kelas pada siswa kelas IX D SMP Negeri 2 Trenggalek semester 1 tahun pelajaran 2015/2016 dalam materi mendeskripsikan kelangsungan hidup makhluk hidup
\end{abstract}

Kata kunci : Mind Map, Adaptasi, Seleksi Alam, Perkembangbiakan

ABSTRACT: The percentage of classical completeness of the class held by researchers is still below $80 \%$. Achievement of the average grade is also less satisfactory only around 65.00. This research was conducted using the stages of implementation in which there are four stages of activity namely: planning, implementing actions, observation and reflection. This class action research was carried out in class IX D because the completeness of this class was the lowest compared to the other classes. The results of the actions in this study look for developments after applying the Mind Map learning model. In cycle 1 the percentage of classical completeness in cycle 1 was $76.00 \%$ and increased to $88.00 \%$ in cycle 2. Likewise, the achievement of the average value increased from 69.20 during cycle 1 to 78.20 in cycle 2 Therefore, it can be concluded that the classroom action research on class IX D students of SMP Negeri 2 Trenggalek in semester 1 of 2015/2016 academic year in the material describes the survival of living things

Keywords: Mind Map, Adaptation, Natural Selection, Breeding

\section{PENDAHULUAN}

Pembaharuan dalam bidang pendidikan harus selalu dilakukan agar ada peningkatan kualitas pendidikan baik secara regional maupun nasional. Menurut Nurhadi dan kawan kawan ada 3 isu utama yang harus diperhatikan yaitu pembaharuan kurikulum, peningkatan kualitas pembelajaran, dan efektifias metode pembelajaran (2004: 1). Selanjutnya dijelaskan bahwa Kurikulum pendidikan harus komprehensif dan 
responsive terhadap dinamika sosial. relevan. tidak overload. dan mampu mengakomodasikan keberagaman keperluan dan kemajuan teknologi. Kualitas pembelajaran harus ditingkatkan untuk meningkatkan kualitas hasil pendidikan. dan secara mikro harus ditemukan strategi atau pendekatan pembelajaran yang efektif di kelas yang lebih memperdayakan potensi siswa.

Sesuai hal tersebut di atas Nurhadi. dkk. (2004:3) mengemukakan persoalan yang ada sekarang adalah: (1) bagaimana menemukan cara terbaik untuk menyampaikan berbagai konsep yang diajarkan di dalam mata pelajaran tertentu. sehingga semua siswa dapat menggunakan dan mengingat lebih lama konsep-konsep tersebut; (2) bagaimana setiap mata pelajaran dipahami sebagi bagian yang saling berhubungan dan membentuk satu pemahaman yang utuh; (3) bagaimana seorang guru dapat berkomunikasi secara efektif dengan siswanya yang selalu bertanya-tanya tentang alasan dari suatu. arti dari sesuatu. dan hubungan dari apa yang mereka pelajari; (4) bagaimana guru dapat membuka wawasan berpikir yang beragam dari seluruh siswa sehingga dapat mempelajari berbagai konsep dan cara mengaitkannya dengan kehidupan nyata.

Dan keempat persoalan tersebut hal yang paling sering dialami oleh peneliti pada saat pengampu mata pelajaran IPA Terpadu kelas kelas IX di SMP Negeri 2 Trenggalek Kabupaten Trenggalek terutama ada 2 hal yang sering dihadapi yaitu belum menemukan cara terbaik untuk menyampaikan konsep yang diajarkan dan cara berkomunikasi yang efektif pada kelas IX. Padahal selain adanya tuntutan ketuntasan ada hal yang lebih besar lagi yang akan mereka hadapi, yaitu menghadapi Ujian Nasional. Hal ini terbukti setelah kegiatan pembelajaran pada KD 1 semester 1 tahun pelajaran 2015/2016. Pada saat kegiatan pembelajaran ketika guru menerangkan tampaknya tidak ada masalah dengan komunikasi dan pemahaman mereka.

Akan tetapi ketika peneliti melakukan uji kompetensi untuk KD ternyata hasil yang mereka peroleh tidak sesuai dengan harapan. Prosentase ketuntasan klasikal dari kelas yang dipegang peneliti masih dibawah $80 \%$. Sehingga peneliti harus mengadakan pembelajaran remidi dulu sebelum kemudian melakukan ulangan remidi. Itupum capaian nilai rata-rata kelas juga sangat jarang memuaskan hanya berkisar 65,00. Padahal setiap siswa sudah dibekali dengan buku cetak dan juga buku pendamping yang berisi latihanlatihan soal. Selain itu peneliti juga membuat Lembar Kerja yang harus merka kerjakan pada saat kegiaatan pembalajaran.

Fakta ini menunjukkan ada hal yang kurang pada saat proses kegiatan pembelajaran berlangsung. Cara mengajar peneliti yang agak terlalu banyak menerangkan dan mungkin kegiatan ini kurang menarik bagi mereka. Selain itu untuk materi-materi yang perlu pemahaman bacaan agak tidak mereka sukai. Padahal materi pada KD 2.1 berikutnya mengidentifikasi kelangsungan hidup makhluk hidup melalui adaptasi, seleksi alam dan perkembangbiakan adalah materi yang cukup banyak. Sehingga peneliti selaku guru kelas IX harus menciptakan kelas yang menyenangkan dengan situasi yang berbeda.

. Untuk itu peneliti mencoba menerapkan salah satu model pembelajaran dari Cooperative Learning yang membentuk komunitas belajar sejak awal yaitu dengan pembentukan kelompok. Sehingga kerjasama sudah terbangun dari awal. Dengan tujuan bahwa mereka akan saling membantu dalam memahami materi yang cukup panjang. 
Sebagaimana yang diungkapkan oleh Felder bahwa dalam pembelajaran kooperatif, siswa bekerja dalam kelompok-kelompok untuk menetapkan tujuan bersama (1994: 2). Hal ini selaras dengan pendapat Slavin didalam Cooperative Learning siswa belajar dalam kelompok kecil dan saling membantu satu sama lain dan memiliki kemampuan yang berbedauntukmencapai tujuanbersama (1997: 2).

Sedangkan model pembelajaran yang dipilih peneliti adalah model pembelajaran Mind Map. Peneliti memilih model pembelajaran ini dengan harapan dapat mengatasi kesulitan mereka dalam menguasai materi yang diajarkan. Dalam proses kegiatan belajar dengan model pembelajaran Mind Map mereka akan bekerja sama mulai pada saat awal pembelajaran sampai mereka bisa menarik kesimpulan sehingga mereka siap untuk melakukan uji kompetensi

Untuk itu dalam kegiatan Penelitian Tindakan Kelas ini peneliti mengambil judul Peningkatan Hasil Belajar Materi Mengidentifikasi Kelangsungan Hidup Makhluk Hidup Melalui Adaptasi, Seleksi Alam Dan Perkembangbiakan Menggunakan Model Pembelajaran Mind Map Kelas IX D Semester 1 Tahun Pelajaran 2015/2016 Di SMP Negeri 2 Trenggalek.

Rumusan masalah dalam kegiatan penelitian ini adalah "Bagaimanakah peningkatan hasil belajar materi mengidentifikasi kelangsungan hidup makhluk hidup melalui adaptasi, seleksi alam dan perkembangbiakan dengan model pembelajaran Mind Map Kelas IX D Semester 1 Tahun Pelajaran 2015/2016 Di SMP Negeri 2 Trenggalek?

\section{KAJIAN PUSTAKA \\ Hasil Belajar}

Frase "hasil belajar" merupakan sebuah frase yang dibentuk dari kata hasil dan kata belajar. Kata "hasil" menurut WJS Poerwodarminto dalam KKBI/Kamus Besar Bahasa Indonesia (1995: 343) adalah sesuatu yang diadakan (dibuat,dijadikan) akibat usaha. Berkaitan dengan kata belajar beberapa ahli telah memdefinisikan kata ini. Ngalim Purwanto (2000:84) yang telah mengutip Hilgarddan Bower, dalam buku Theories of Learning (1975) mengatakan bahwa belajar merupakan proses yang menghasilkan atau melahirkan atau mengubah suatu kegiatan melalui latihan-latihan yang dibedakan dari perubahan-perubahan oleh faktor-faktor yang tidak termasuk latihan.

Sedangkan W.S. Winkel (1989:36) mendefinisikan bahwa belajar adalah aktifitas mental yang belangsung dalam kegiatan interaktif dengan linkungan sehingga dapat menghasilkan perubahan-perubahan dalam pengetahuan, pemahaman, keterampilan, dan nilai sikap. Perubahan itu relatif konstan dan berbekas. Hal ini sejalan dengan yang diungkapkan oleh Nana Sujana (1998: 5) bahwa belajar adalah suatu proses yang ditandai dengan adanya suatu perubahan pada diri seseorang.

Dengan demikian dapat dikatakan bahwa belajar adalah merupakan suatu proses kegiatan yang ditandai dengan adanya perubahan tingkah laku seserong. Oleh karena itu dapat dikatakan bahwa orang sudah belajar apabila dia menunjukkan adanya perubahan dalam bentuk tingkah laku, sikap, kebiasaan, penguasaan pengetahuan, percakapan, dan lain-lain. 
Berdasarkan pengertian-pengertian di atas maka dapat disimpulkan bahwa hasil belajar adalah kemampuan yang dimiliki seseorang yang wujudnya bisa berupa kemampuan kognitif, afektif, dan psikomotor. Sehingga salah satu tugas sekolah adalah memberikan pengajaran kepada siswa. Mereka harus memperoleh kecakapan dan pengetahuan dari sekolah, di samping mengembangkan pribadinya. Pemberian kecakapan dan pengetahuan kepada siswa, yang merupakan proses belajar-mengajar yang dilakukan oleh guru di sekolah dengan menggunakan cara-cara atau metode-metode tertentu (Suryosubroto, 1997: 148).

Materi Mengidentifikasi Kelangsungan Hidup Makhluk Hidup Melalui Adaptasi, Seleksi Alam Dan Perkembangbiakan

a) Mengidentifikasi Kelangsungan Hidup Makhluk Hidup Melalui Adaptasi

Tri Widodo dan kawan-kawan (2009:54) dalam BSE IPA Terpadu untuk SMP IX. mengatakan bahwa semakin tinggi kemampuan adaptasi suatu jenis organisme, maka semakin besar pula kemungkinan kelangsungan hidup jenis organisme itu. Dengan kemampuan adaptasi yang tinggi, suatu jenis dapat menempati habitat yang beraneka. Manusia adalah contoh jenis makhluk yang mempunyai kemampuan adaptasi yang tinggi. Hampir semua habitat dihuni oleh manusia. Mulai dari pantai sampai pegunungan Andes yang tinggi, dari hutan tropis yang panas dan lembab sampai gurun pasir yang kering dan panas, serta daerah kutub yang dingin. Dengan kemampuan adaptasi yang sangat tinggi, populasi manusia terus bertambah dan menduduki habitat baru, hal ini karena kemampuan otaknya yang paling tinggi dibanding organisme lainnya. Dengan berbekal sains, manusia mampu menciptakan berbagai peralatan untuk mengatasi kesulitan yang dihadapinya.

Selanjutnya disebutkan juga ada 3 jenis adaptasi yaitu adaptasi morfologi, fisiologi dan tingkah laku

1) Adaptasi Fisiologis

Elok Sudibyo dan kawan-kawan dalam buku BSE Mari Belajar IPA untuk SMP dan Mts mengatakan bahwa adaptasi fisiologis adalah penyesuaian makhluk hidup melalui fungsi organ-organ tubuh supaya bertahan hidup. Adaptasi ini agak sulit diamati karena berada didalam tubuh. (2008: 76) Sebagai contohnya adalah perbedaan urin pada ikan. Urin ikan dilaut lebih pekat karena kadar garam air lebih tinggi sehingga ikan laut harus lebih sering minum yang berkibat kadar garam dalam tbuhnya akan naik. Untuk itu harus dibuang melalui urin. Sedangkan hewan-hewan herbivora beradaptasi melalui makanan. adaptasi fisiologi yang terdapat pada tumbuhan juga dicontohkan pada bunga yang menghasilkan madu atau nektar, bau khas pada bunga dapat mengundang serangga untuk datang, sehingga dapat membantu penyerbukan. (Elok Sudibyo. 2008: 77)

2) Adaptasi Morfologi

Tri Widodo mengatakan bahwa adaptasi morfologi adalah perubahan bentuk tubuh atau struktur alat-alat tubuh tertentu dai suatu organusme terhadap lingkungannya 
(2009:54). Adaptasi morfologi adalah adaptasi yang paling mudah dilihat. Salah satu contoh yang diberikan adalah adaptasi pada hewan. Seperti pada gambar 2.1 adalah contoh adaptasi morfologi kaki (cakar burung) yang mentesuaikan dengan tempat dan cara hidupnya, pada itik kakinya dilengkapi dengan selaput karena mempunyai fungsi untuk membantu mendayung saat berada di air. Sebaliknya kaki elang dilengkapi dengan kuku yang kuat dan tajam karena digunakan untuk mencengkeram mangsanya.

Contoh adaptasi morfologi pada tumbuhan adalah pada tanaman enceng gondok (Euchornia crasipes) yang hidup di air, paku air (Azolla pinata) dan teratai. Tumbuhan ini memiliki angkai daun yang menggembung membentuk rongga-rongga udara yang berisi udara sehingga dapat mengapung. Tumbuhan yang hidup di air umumnya mempunyai lapisan kutikula yang tipis dan mudah ditembus air. Melalui permukaan tubuh yang tipis inilah tumbuhan dapat mengambil air dan zat-zat hara melalui seluruh permukaan tubuhnya. Tumbuhan yang sebagian tubuhnya berada di dalam air dan sebagian di atas air memiliki sistem perakaran serabut sebagai alat melekat dan sistem jaringan pengangkut pada tumbuhan air tidak berkembang dengan baik. Stomata terletak di permukaan daun sebelah atas serta memiliki jumlah daun yang banyak, lebar dan tipis. 1) Adaptasi Tingkah Laku

Menurut TIM Abdi Guru dalam buku IPA Terpadu 3 adaptasi tingkah laku adalah kemampuan makhluk hidup menyesuaikan dir terhadap lingkungannya berdasarkan pada tingkah laku (2007: 96). Adaptasi ini terjadi pada kegiatan organisme tersebut, sehingga mudah untuk diamati. Banyak contoh yang bisa dilihat dalam kehidupan sehari-hari, misalnya mamalia laut seperti paus akan sering muncul ke permukaan air untuk mengambil oksigen dan mengeluarkan dara yangpernapasan yang jenuh melalui uap air. Pada musim dingin banyak binatang yang bermigrasi ke tempat yang lebih hangat untuk mencari makanan. Pohon jati menggugurkan daunnya dimusim kemarau untuk mengurangi penguapan.

b) Mengidentifikasi Kelangsungan Hidup Makhluk Hidup Melalui Seleksi Alam

Menurut Elok Sudibyo dan kawan-kawan seleksi alam ditentukan oleh beberapa faktor diantaraya adalah 1) suhu lingkungan; dengan contoh hanya hewan yang berbulu tebal yang sanggup, hewan yang berbulu tipis akan tereliminasi, 2) makanan; apabila terjadi perebutan makanan, maka hanya hewan yang kuat yang mampu bertan dan 3) cahaya matahari; matahari akan menjadi penentu utama bagi tumbuhan yang berklorofil untuk bertahan hidup. (2008:80).

Sedangkan menurut Yadi Nurhayadi dan Rini Rachmatika faktor biotik dan abiotik yang akan menjadi penyeleksi. Perubahan pada faktor biotik bisa memacu adanya persaingan antar populasi yang bisa mengakibatkan tersingkirnya suatu spesies. Demikian juga perubahan lingkungan abiotik akan memiliki pengaruh yang besar pada kelangsungan suatu organisme. Sebagai contohnya setelah ada revolusi industri di Inggris terjadi polusi dari asap pabrik sehingga spesies kupu-kupu yang bersayap terang semakin jarang terlihat karena dia mudah ditangkap oleh pemangsa pada saat hinggap di pohon 
yang gelap (2010:53)

Jadi dapat disimpulkan bahwa pengertian seleksi alam adalah alam menyeleksi atau memilih individu-individu yang memiliki sifat-sifat sesuai dan melenyapkan individu-individu yang memiliki sifat-sifat yang tidak sesuai dengan lingkungannya. Hanya individu-individu yang dapat menyesuaikan diri dengan lingkungannya akan dapat hidup terus. Adapun organisme yang tidak dapat menyesuaikan diri dengan lingkungannya akan punah. Berdasarkan kenyataan tersebut maka adaptasi terhadap lingkungannya merupakan salah satu mekanisme seleksi alam. (Tri Widodo, 2009:65) c) Mengidentifikasi Kelangsungan Hidup Makhluk Hidup Melalui Perkembangbiakan

Perkembangbiakan makhluk hidup dapat digunakan untuk melangsungkan kehidupan. Kemampuan berkembang biak makhluk hidup tidak sama ada yang tinggi ada yang rendah. Menurut Elok Sudibyo (2008: 85-87) makhluk hidup dapat berkembang dengan vegetatif yakni perkembangbiakan yang tidak melibatkan sel kelamin atau aseksual dan generatif atau perkembangbiakan seksual.

1) Perkembangbiakan Vegetatif

Perkembangbiakan vegetatif ada 2 macam yakni vegetatif alami dan buatan. Vegetatif alami adalah perkembangbiakan yang berlangsung alami tanpa ada campur tangan manusia. Alat reproduksi vegetatif alami diantaranya adalah :

- Tunas yaitu tumbuhan muda yang tumbuh dari ujung batang atau ketiak daun. Ada 2 macam tunas yaitu tunas adventif dan tunas biasa. Tunas adventif adalah tunas yang keluar dari selain dari ujung batang atau ketiak daun (tunas adventif) seperti pada pisang dan cocor bebek sedangkan tunas biasa adalah tunas yang tumbuh dari ujung batang atau ketiak daun

- Umbi adalah tempat untuk menyimpan makanan. Tetapi umbi juga berfungsi sebagai alat untuk perkembangbiakan seperti pada ketela rambat, kentang da bawang

- Rhizoma adalah perkembangbiakan dengan cara adanya batang yang menjalar di bawah tanah. Contoh perkembangbiakan ini adalah pada tanaman laos, kencur dan jahe.

- Stolon perkembangbiakan dengan cara adanya batang yang menjalar di permukaan tanah. Contoh perkembangbiakan ini adalah pada tanaman pegagan, arbei dan rumput teki

Sedangkan vegetatif buatan biasanya perkembangbiakan yang dilaksanakan secara sengaja untuk pembudidayaan tanaman, misalnya mencangkok, merunduk, dan menyambung.

2) Perkembangbiakan secara kawin atau generatif

Perkembangbiakan secara kawin atau generatif menurut Tri Widodo (2009: 6164) yaitu perkembangbiakan yang ditandai dengan adanya peleburan dua buah sel menjadi satu. Proses peleburan dua sel gamet yang berbeda jenisnya disebut pembuahan 
atau fertilisasi. Hasil dari pembuahan adalah sebuah sel zigot yang akan tumbuh menjadi embrio, kemudian berkembang menjadi keturunan baru.

Keturunan baru mewarisi beberapa sifat yang dimiliki oleh kedua induknya. Keturunan baru yang dihasilkan tidak selalu sama dengan kedua induknya. Dalam perkembangbiakan secara kawin akan menghasilkan bermacam-macam variasi. Hal ini menyebabkan terjadinya keanekaragaman pada makhluk hidup Pada hewan dan tumbuhan tingkat rendah, perkembangbiakan secara generatif terjadi dengan cara konjugasi atau peleburan dua sel gamet. Konjugasi adalah perkembangbiakan secara kawin pada makhluk hidup yang belum jelas alat kelaminnya. Konjugasi ini terjadi pada Amoeba, Paramaecium, Spirogyra, serta hewan dan tumbuhan rendah lainnya. Pada peleburan dua sel gamet dikenal dua macam, yaitu isogami dan anisogami. Isogami adalah peleburan dua sel gamet di mana sel jantan dan betina mempunyai bentuk dan ukuran yang sama, contoh ganggang Ulotrich dan Chamidomonas. Adapun anisogami adalah peleburan dua sel gamet di mana bentuk dan ukuran sel kelamin jantan dan betina tidak sama. Pada umumnya, sel kelamin betina mempunyai ukuran yang lebih besar daripada sel kelamin jantan. Hal ini ditemukan pada plas-modium dan oedogonium. Pada tumbuhan tingkat tinggi, proses pertemuan organ seks betina (putik) dan gamet jantan (serbuk sari) disebut penyerbukan. Proses penyerbukan memungkinkan kedua gamet bertemu dalam suatu tempat. Setelah bertemu, kedua gamet tersebut melebur membentuk sel baru yang disebut pembuahan atau fertilisasi. Dengan fertilisasi ini, kedua inti gamet yang mengandung bahan yang akan diwariskan kepada keturunannya bersatu. Inti sel yang dapat diwariskan kepada keturunan berikutnya itu dinamakan kromosom. Pada setiap jenis organisme atau spesies memiliki jumlah kromosom yang tertentu. Dengan kata lain, jumlah kromosom untuk tiap jenis organisme tidak sama. Adapun banyaknya kromosom untuk setiap zigot sama dengan jumlah kromosom sel induknya. Hal ini terjadi karena zigot tersebut terbentuk dari peleburan dua gamet yang berasal dari induknya. Banyaknya kromosom dalam suatu gamet hanya separuh dari jumlah kromosom dalam zigot. Artinya, banyaknya kromosom dalam suatu gamet berbeda dengan banyaknya kromosom dalam zigot.

Pada tumbuhan tingkat tinggi, proses pertemuan organ seks betina (putik) dan gamet jantan (serbuk sari) disebut penyerbukan. Proses penyerbukan memungkinkan kedua gamet bertemu dalam suatu tempat. Setelah bertemu, kedua gamet tersebut melebur membentuk sel baru yang disebut pembuahan atau fertilisasi. Dengan fertilisasi ini, kedua inti gamet yang mengandung bahan yang akan diwariskan kepada keturunannya bersatu. Inti sel yang dapat diwariskan kepada keturunan berikutnya itu dinamakan kromosom.

\section{Model Pembelajaran Mind Map}

Dalam Cooperative learning pelibatan siswa dalam kegiatan pembelajaran adalah hal yang mutlak. Johnson dalam Santoso mengatakan bahwa Cooperative Learning 
kegiatan belajar mengajar secara kelomo-kelompok kecil siswa belajar dan bekerja sama untuk sampai kepada pengalaman belajar yang optimal, baik pengalaman individu maupun kelompok (Santoso, B: 1999).

Model pembelajaran Mind Map yakni mind berarti pikiran, dan map berarti peta. Pengertian Mind Map, menurut sang pengembang, Tony Buzan (2005: 75) adalah suatu teknik mencatat yang menonjolkan sisi kreativitas sehingga efektif dalam memetakan pikiran. Teknik mencatat melalui peta pikiran (mind map) ini dikembangkan berdasarkan bagaimana cara otak bekerja selama memproses suatu informasi. Sebagaimana yang diungkapkan oleh Anton dalam blognya bahwa berdasarkan hasil penelitian mennjukkan bahwa otak kita tidak menyimpan informasi di dalam kotak-kotak sel saraf yang terjajar rapi melainkan dikumpulkan dalam sel-sel yang bercabang-cabang yang apabila dilihat sekilas akan berbentuk seperti cabang-cabang pohon.

Konsep Mind Map asal mulanya diperkenalkan oleh Tony Buzan tahun 1970-an. Teknik ini dikenal juga dengan nama Radiant Thinking. Sebuah mind map memiliki sebuah ide atau kata sentral, dan ada 5 sampai 10 ide lain yang keluar dari ide sentral tersebut. Mind Map sangat efektif bila digunakan untuk memunculkan ide terpendam yang kita miliki dan membuat asosiasi di antara ide tersebut. Mind Map juga berguna untuk mengorganisasikan informasi yang dimiliki. Bentuk diagramnya yang seperti diagram pohon dan percabangannya memudahkan untuk mereferensikan satu informasi kepada informasi yang lain.

Mind Map merupakan tehnik penyusunan catatan demi membantu siswa menggunakan seluruh potensi otak agar optimum. Caranya, menggabungkan kerja otak bagian kiri dan kanan. Dengan metode mind mapping siswa dapat meningkatkan daya ingat hingga $78 \%$.

Ada banyak manfaat atau keunggulan yang dapat diraih bila siswa menggunakan teknik mencatat mind map (peta pikiran) ini dalam kegiatan pembelajarannya, di antaranya:

a. Mind map meningkatkan kreativitas dan aktivitas individu maupun kelompok,

b. Mind map memudahkan otak memahami dan menyerap informasi dengan cepat,

c. Mind map meningkatkan daya ingat,

d. Mind map dapat mengakomodasi berbagai sudut pandang terhadap suatu informasi,

e. Mind map dapat memusatkan perhatian siswa,

f. Mencatat dengan teknik mind map menyenangkan,

g. Mind map mengaktifkan seluruh bagian otak.

Mind Map menggunakan teknik penyaluran gagasan dengan menggunakan kata kunci bebas, simbol, gambar, dan menggambarkan secara kesatuan dengan menggunakan teknik pohon. Untuk membuat Mind Map terlebih dahulu siapkan selembar kertas kosong yang diatur dalam posisi landscape kemudian tempatan topik yang akan dibahas di tengah-tengah halaman kertas dengan posisi horizontal. Usahakan menggunakan gambar, simbol atau kode pada Mind Map yang dibuat. Dengan visualisasi kerja otak kiri yang 
bersifat rasional, numerik dan verbal bersinergi dengan kerja otak kanan yang bersifat imajinatif, emosi, kreativitas dan seni. Dengan ensinergikan potensi otak kiri dan kanan, siswa dapat dengan lebih mudah menangkap dan menguasai materi pelajaran.

Selain itu, siswa dapat menggunakan kata-kata kunci sebagai asosiasi terhadap suatu ide pada setiap cabang pemikiran berupa sebuah kata tunggal serta bukan kalimat. Setiap garis-garis cabang saling berhubungan hingga ke pusat gambar dan diusahakan garis-garis yang dibentuk tidak lurus agar tidak membosankan. Garis-garis cabang sebaiknya dibuat semakin tipis begitu bergerak menjauh dari gambar utama untuk menandakan hirarki atau tingkat kepentingan dari masing-masing garis.

Adapun penerapan model pembelajaran Mind Map dalam kegiatan pembelajaran materi Mendeskripsikan kelangsungan hidup makhluk hidup pada indikator melalui adaptasi, selekasi alam dan perkembangbiakan di kelas IX D semester 1 tahun pelajaran 2015/2016 adalah sebagai berikut:

1) Guru melakukan tanya jawab yang berkaitan dengan materi

- Tahukah kamu perbedaan kaki/cakar ayam dengan bebek?

- Apakah yang kamu lakukan pada saat dibawah pada terik matahari?

- Apakah ikan di air juga minum?

2) Guru meminta siswa duduk berkelompok yang terdiri dari 4 siswa

3) Guru menjelaskan tentang aturan model pembelajaran mind mapping

- Setiap kelompok akan menerima lembar kerja yang berisi 1 lingkaran ditengahtengah kertas

- Setiap kelompok harus membuat mapping berdasarkan tema yang diberikan

- Kelas akan dibagi menjadi 2 kelompok besar A ( 3 kelompok) dan B (3 kelompok) Kelompok A membuat mapping tentang indikator 1 Mendeskripsikan kelangsungan hidup makhluk hidup melalui adaptasi

Kelompok B membuat mapping tentang indikator 2 Mendeskripsikan kelangsungan hidup makhluk hidup melalui seleksi alam

4) Guru membagikan Lembar kerja kepada setiap kelompok

5) Siswa membuat mapping dari materi yang diberikan secara kelompok

6) Guru dan siswa mendiskusikan hasil kerja kelompok dengan menuliskan di papan tulis

7) Kelompok lain melengkapi bila ada bagian yang kurang.

8) Setiap kelompok membuat kesimpulan dari mapping yang sudah didiskusikan

9) Guru meminta salah satu anggota kelompok untuk membacakan hasil kesimpulan dari pekerjaan pada pertemuan sebelumnya

10) Kelompok lain dengan materi yang sama diberikan kesempatan untuk menanggapi apabila ada kekurangan dari presentasi kelompok lain

11) Guru memberikan soal-soal pendek untuk didiskusikan bersama kelompok

12) Guru dan siswa mendiskusikan jawaban

13) Guru meminta siswa untuk kembali ke tempat duduknya 
Guru memberikan soal uji kompetensi yang dikerjakan secara individu

\section{METODE PENELITIAN \\ Rancangan Penelitian}

Penelitian tindakan Kelas ini bertujuan untuk meningkatkan hasil belajar siswa dalam pembelajaran. Proses pelaksanaan penelitian dilaksanakan secara kolaborasi yang bersifat partisipan artinya adanya keterlibatan secara aktif antara peneliti dan kolaborator. Penelitian ini dilakukan dengan menggunakan tahap-tahap pelaksanaan yang didalamnya terdapat empat tahap kegiatan yaitu: perencanaan (planning), pelaksanaan tindakan (acting), observasi (observing) dan refleksi (reflecting), (Kurt Lewin, dalam Rochiati 2006: 83).

Adapun penelitian ini dilaksanakan dalam dua siklus, yang masing-masing siklus dilaksanakan kegiatan-kegiatan sebagai berikut:

\section{Tahap Rencana Tindakan}

Dalam tahap ini peneliti dibantu oleh kolaborator melakukan kegiatan dalam merancang persiapan yang akan dilaksanakan dalam penelitian tindakan kelas diantaranya adalah:

a. Menyusun silabus pembelajaran materi mendeskripsikan kelangsungan hidup makhluk hidup melalui adaptasi dan selekasi alam dengan model pembelajaran Mind Map

b. Menyusun rencana pelaksanaan pembelajaran (RPP) pembelajaran materi mendeskripsikan kelangsungan hidup makhluk hidup melalui adaptasi dan selekasi alam dengan model pembelajaran Mind Map

c. Menyusun Lembar kerja siswa yang disesuaikan dengan Rencana Pelaksanaan Pembelajaran

d. Menyusun instrumen-instrumen yang lain seperti Lembar Jawaban, Daftar Hadir dan lain-lain

\section{Tahap Pelaksanaan}

Tindakan penelitian dilaksanakan dua siklus, tiap siklusnya dilaksanakan dalam 2 kali pertemuan atau 4 x 40 menit. Pelaksanaan siklus 1 pada penelitian ini direncanakan hari Senin tanggal 7 September 2015 dan hari Selasa tanggal 8 september 2015. Adapun materi pada pada siklus 1 adalah indikator Mendeskripsikan kelangsungan hidup makhluk hidup melalui adaptasi dan seleksi alam.

Hal-hal yang dilaksanakan pada tahap tindakan dalam kegiatan pembelajaran adalah sebagai berikut:

\section{Pertemuan Pertama}

1) Guru melakukan tanya jawab yang berkaitan dengan materi

- Tahukah kamu perbedaan kaki/cakar ayam dengan bebek?

- Apakah yang kamu lakukan pada saat dibawah pada terik matahari?

- Apakah ikan di air juga minum? 
2) Guru meminta siswa duduk berkelompok yang terdiri dari 4 dan 5 siswa

3) Guru menjelaskan tentang aturan model pembelajaran mind Map

- Setiap kelompok akan menerima lembar kerja yang berisi 1 lingkaran ditengahtengah kertas

- Setiap kelompok harus membuat Map berdasarkan tema yang diberikan

- Kelas akan dibagi menjadi 2 kelompok besar A ( 3 kelompok) dan B (3 kelompok)

- Kelompok A membuat Map tentang indikator 1 Mendeskripsikan kelangsungan hidup makhluk hidup melalui adaptasi

- Kelompok B membuat Map tentang indikator 2 Mendeskripsikan kelangsungan hidup makhluk hidup melalui seleksi alam

4) Guru membagikan Lembar kerja kepada setiap kelompok

5) Siswa membuat Map dari materi yang diberikan secara kelompok

6) Guru dan siswa mendiskusikan hasil kerja kelompok dengan menuliskan di papan tulis

7) Kelompok lain melengkapi bila ada bagian yang kurang.

8) Setiap kelompok membuat kesimpulan dari Map yang sudah didiskusikan

\section{Pertemuan Kedua}

1) Guru melakukan tanya jawab yang berkaitan dengan materi

- Ada berapa macam cara makhluk hidup melangsungkan hidupnya melalui adaptasi?

- Tahukah kamu hewan yang beradaptasi secara fisiologi?

- Kelangsungan hidup makhluk hidup melalui seleksi alam?

2) Guru meminta siswa untuk duduk kembali bersama kelompoknya

3) Guru meminta salah satu anggota kelompok untuk membacakan hasil kesimpulan dari pekerjaan pada pertemuan sebelumnya

4) Kelompok lain dengan materi yang sama diberikan kesempatan untuk menanggapi apabila ada kekurangan dari presentasi kelompok lain

5) Guru memberikan soal-soal pendek untuk didiskusikan bersama kelompok

6) Guru dan siswa mendiskusikan jawaban

7) Guru meminta siswa untuk kembali ke tempat duduknya

8) Guru memberikan soal uji kompetensi yang dikerjakan secara individu

\section{Tahap Observasi}

Kegiatan observasi atau pengamatan dilakukan untuk mengamati kesesuaian antara rencana pelaksanaan pembelajaran dengan proses kegiatan pembelajaran. selain itu kolaborator juga mengamati penerapan model pembelajaran Mind Map di dalam kelas. Diskusi antara peneliti dan kolaborator demi kemajuan pembelajaran dilaksanakan pada setiap akhir siklus.

\section{Tahap Refleksi}

Pada tahap refleksi peneliti meninjau pelaksanaan pembelajaran dengan mengkaji ulang RPP, menilai hasil belajar siswa untuk menentukan tingkat ketercapaian KKM. Pada tahap ini sejauh mana intervensi yang telah dilakukan dengan pendekatan Mind Map telah menghasilkan perubahan hasil belajar yang signifikan. Bila hal yang dikehendaki peneliti berhasil, maka penelitian dapat dikatakan efektif. Bila belum berhasil, maka peneliti harus melakukan siklus selanjutnya. 


\section{Subjek Penelitian}

Penelitian tindakan kelas ini dilaksanakan di kelas IX D SMP Negeri 2 Trenggalek semester 1 tahun pelajaran 2015/2016. Peneliti adalah Anik Widiarti, S.Pd. M.Pd selaku Guru pengampu mata pelajaran IPA. Dalam melaksanakan semua rangkaian kegiatan penelitian, peneliti didampingi oleh guru mata pelajaran serumpun yakni Ibu Winarni, S.Pd. yang membantu sebagai Kolaborator. Penelitian ini memilih kelas IX D dengan alasan ketuntasan kelas ini adalah yang paling rendah dibandingkan dengan kelas-kelas yang lain. Kelas IX D ini yang berjumlah 25 siswa yang terdiri dari 12 siswa putra dan 13 siswa putri. Instrumen penelitian adalah tes tulis berbentuk pilihan ganda dengan jumlah 20 soal. Adapun pelaksanaan tes adalah pada akhir pertemuan 2 pada masing-masing siklus

\section{Analisis Data}

1) Menetapkan Pedoman Penilaian

Skor yang didapat dari tes siklus 1, dan tes siklus 2, kemudian dikonversikan menjadi nilai. Untuk mengubah skor menjadi nilai maka dilakukan konversi skor kedalam nilai atau $z$ skor yaitu nilai yang berskala 1 - 100 (Anas Sudijono, 2003:313) dengan menggunakan rumus konversi berikut ini:

$$
\text { Nilai }=\frac{\text { Jumlah Maks Skor }}{\text { Skor Maks Ideal }} \times 100 \%
$$

Sesuai dengan yang sudah ditetapkan pada kurukulum di SMP Negeri 2 Trenggalek, KKM nilai IPA pada KD 2.1 dengan materi mendeskripsikan kelangsungan hidup makhluk hidup melalui adapatasi, seleksi alam dan perkembangbiakan adalah 70 . Jadi seorang siswa dinyatakan berhasil mencapai KKM apabila nilai peolehan siswa diatas atau sama dengan 70

2) Prosentase ketuntasan

Selanjutnya setelah mendapatkan hasil individu maka langkah berikutnya adalah mencari Prosentase ketuntasan kelas. dengan cara membagi jumlah siswa yang telah tuntas dengan jumlah seluruh siswa kemudian dikalikan 100 persen:

$$
\mathrm{PK}=\frac{\sum K}{\sum S} \times 100 \%
$$

Keterangan:

PK: Presentasi ketuntasan

$\sum K$ : Jumlah siswa yang tuntas

$\sum S$ : Jumlah seluruh siswa

$100 \%$ : Standar presentase ideal

Target pencapaian prosentase ketuntasan kelas adalah $85 \%$. Maka bila prosentase yang dicapai dibawah $85 \%$, penelitian dinilai belim berhasil. Dan apabila hasil presentase penelitian tindakan kelas sama atau lebih dari $85 \%$ maka penelitian tondakan kelas dinilai sudah berhasil 
3) Nilai rata-rata

Capaian yang ditargetkan oleh peneliti dan kolaborator adalah 75. Apabila nilai rata-rata kelas sama atau lebih 75 maka kegiatan pembelajaran penlitian ini dianggap berhasil. Sebaliknya, apabila nilai rata-rata kelas kurang dari 75, maka penelitian ini dianggap belum berhasil

Adapun rumus untuk menentukan nilai rata-rata adalah sebagai berikut:

$$
\mathrm{RN}=\frac{\sum N}{\sum S}
$$

Keterangan:

$\mathrm{RN}$ : Nilai rata-rata

$\sum N$ : Jumlah nilai seluruh siswa

$\sum S$ : Jumlah seluruh siswa

4) Memadukan perolehan data secara keseluruhan untuk menuju pada kesimpulan melalui grafik perbandingan.

\section{HASIL DAN PEMBAHASAN}

Hasil akhir dari penelitian tindakan kelas dengan menerapkan model pembelajaran Mind Map pada materi mendeskripsikan kelangsungan hidup makhluk hidup melalui adaptasi, seleksi alam, dan perkembangbiakan adalah peningkatan hasil belajar siswa kelas IX D tahun pelajaran 2015/2016. Perbandingan hasil belajar siswa siklus 1 dan siklus 2 dapat diketahui dari tabel 4.1 berikut ini:

Tabel 1. Perbandingan Hasil Belajar Siswa Siklus 1 dan Siklus 2

\begin{tabular}{|l|l|c|c|}
\hline No. & \multicolumn{1}{|c|}{ Aspek } & Siklus 1 & Siklus 2 \\
\hline 1. & Nilai Rata-rata & 69,20 & 78,20 \\
\hline 2. & Prosentase Ketuntasan & $76,00 \%$ & $88,00 \%$ \\
\hline 3. & $\begin{array}{l}\text { Prosentase } \\
\text { Ketidaktuntasan }\end{array}$ & $24,00 \%$ & $12,00 \%$ \\
\hline 4. & Nilai Tertinggi & 95 & 100 \\
\hline 5. & Nilai Terendah & 55 & 60 \\
\hline
\end{tabular}

Dari tabel diatas dapat diketahui peningkatan hasil belajar kelas IX D dari siklus 1 dan siklus 2. Apabila dibandingkan antara siklus 1 dan siklus telah terjadi peningkatan pada nilai rata-rata siswa yang semula 69,20 menjadi 78,20. Demikian pula dengan prosentase ketuntasan klasikal. Pada siklus 2 sudah mencapai $88,00 \%$. Jadi siswa yang tidak tuntas hanya $12,00 \%$ atau hanya tinggal 3 siswa saja. Bahkan sudah muncul nilai sempurna pada siklus 2. Ada 2 siswa yang mampu mendapatkan nilai 100. Begitu juga nilai terendah yang semula 55 pada siklus 1 menjadi 60. Perkembangan hasil belajar siswa kelas IX D semester 1 tahun pelajaran 2015/2016 apabila dikonversikan dalam grafik dapat dibaca dari gambar 1 berikut ini 


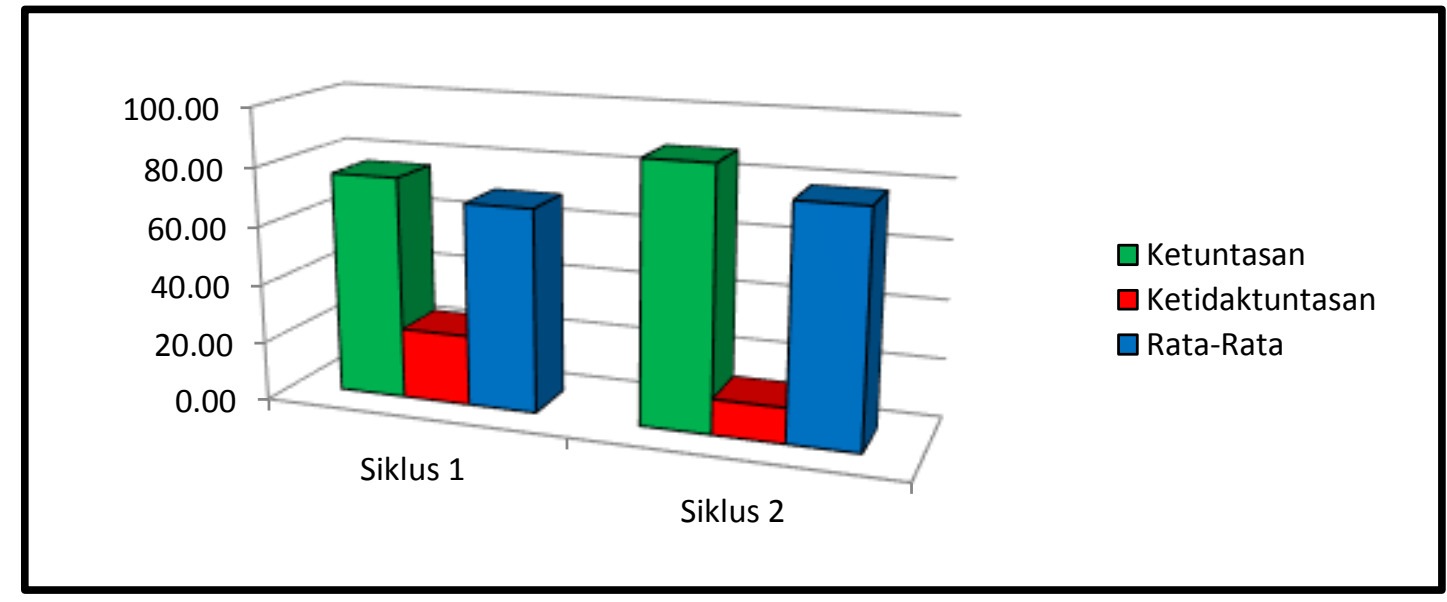

Gambar 1. Peningkatan Hasil Belajar Siswa Siklus 1 dan Siklus 2

Dari gambar diatas terlihat perkembangan nyata dari siklus 1 ke siklus 2, prosentase siswa yang belum tuntas (warna merah) siklus 1 sebesar 24,00\% atau 6 siswa pada siklus 2 berkurang tinggal $12,00 \%$ atau 3 siswa saja. Sedangkan prosentase siswa yang tuntas (warna hijau) siklus 1 sebesar 76,00\% meningkat 88,00\% pada siklus 2. Demikian juga dengan nilai rata-rata siswa kelas IX D (warna biru), capaian pada saat siklus 1 sebesar 69,20. Pada saat siklus 2 capaian nilai rata-rata kelas meningkat menjadi 78,20 . Berdasarkan hasil tes uji kompetensi siklus 1 dan 2 pada penelitian tindakan kelas ini, maka peneliti dan kolaborator menyepakati bahwa hasil ini sudah memenuhi target yang ditentukan, artinya penelitian tindakan kelas pada siswa kelas IX D SMP Negeri 2 Trenggalek semester 1 tahun pelajaran 2015/2016 dalam materi mendeskripsikan kelangsungan hidup makhluk hidup melalui adaptasi, seleksi alam dan perkembangbiakan dengan model pembelajaran Mind Map telah berhasil.

\section{KESIMPULAN}

Terjadi peningkatan hasil belajar kelas IX D dari siklus 1 dan siklus 2. Apabila dibandingkan antara siklus 1 dan siklus telah terjadi peningkatan pada nilai rata-rata siswa yang semula 69,20 menjadi 78,20. Demikian pula dengan prosentase ketuntasan klasikal. Pada siklus 2 sudah mencapai $88,00 \%$. Jadi siswa yang tidak tuntas hanya $12,00 \%$ atau hanya tinggal 3 siswa saja. Bahkan sudah muncul nilai sempurna pada siklus 2 . Ada 2 siswa yang mampu mendapatkan nilai 100. Begitu juga nilai terendah yang semula 55 pada siklus 1 menjadi 60. Berdasarkan hasil tes uji kompetensi siklus 1 dan 2 pada penelitian tindakan kelas ini, maka peneliti dan kolaborator menyepakati bahwa hasil ini sudah memenuhi target yang ditentukan, artinya penelitian tindakan kelas pada siswa kelas IX D SMP Negeri 2 Trenggalek semester 1 tahun pelajaran 2015/2016 dalam materi mendeskripsikan kelangsungan hidup makhluk hidup melalui adaptasi, seleksi alam dan perkembangbiakan dengan model pembelajaran Mind Map telah berhasil. 


\section{DAFTAR RUJUKAN}

Buzan, Toni. 2005. Mind Map untuk Meningkatkan Kreativitas.Jakarta: PT Gramedia Pustaka Utama

Felder, R.M. 1994. “Any Questions?” Chem. Engr. Education, 28(3), 174-175. <www.ncsu.edu/felder-public/Columns/Questions.pdf>.

Djohan (2008). Aplikasi Real-time Buzan Mind Maping. Indomindamp Learning CenterILC Applied RT-MM. Pdf.

Nurhadi, dkk. (2004). Pembelajaran Kontektual dan Penerapannya dalam KBK. Malang: Universitas Negeri Malang.

Nurhayadi, Yadi dan Rini Rachmatika. 2010. IPA Terpadu untuk SMP dan Mts. Fisika, Biologi dan Kimia. Jakarta. Pusat Perbukuan Kementruian Pendidikan Nasional

Purwanto, M. Ngalim. 2000. Psikologi Pendidikan. Bandung: Remaja Rosdakarya.

Slavin, R.E. 1997. Cooperative Learning: Theory, Research, and Practice. Massachusetts: Allyn and Bacon Publishers.

Rochiati Wiriaatmadja. 2006. Metode Penelitian Tindakan Kelas untuk Meningkatkan Kinerja Guru dan Dosen. Bandung: Remaja Rosdakarya.

Sudibyo Elok et. al. 2008. BSE Mari Belajar IPA untuk SMP dan Mts Jakarta. Pusat Perbukuan Kementrian Pendidikan Nasional

Sudijono, Anas. 2003. Pengantar Evaluasi Pendidikan. Jakarta: PT. Raja Grafindo Persada, Cet. XII

Santoso, B.Cooperative Learning: Penerapan Tekhnik Jigsaw Dalam Pembelajaran Bahasa Indonesia di SLTP. Buletin Pelangi Pendidikan. Vol. 1. No. 1. 1999.

Sudjana, Nana, 1998, Dasar-Dasar Proses Belajar Mengajar, Bandung: Sinar Baru Algesindo

Suryosubroto,B. 1997.Prinsip Memilih Media Pembelajaran. Jakarta: Rineka Cipta.

Tim Abdi Guru. 2007. IPA TERPADU 3. Jakarta. Erlangga

Widodo, Tri et.al. 2009. IPA Terpadu untuk SMP IX. Jakarta. Pusat Perbukuan Kementruian Pendidikan Nasional

Winkel, WS. (1989). Psikolog Pengajaran. Jakarta: Raja Grafindo Persada. 
Volume 3, Nomor 2, Agustus 2019 